\title{
A single erythroid-specific DNase I super-hypersensitive site activates high levels of human $\beta$-globin gene expression in transgenic mice
}

\author{
Thomas M. Ryan, ${ }^{1}$ Richard R. Behringer, ${ }^{2}$ Nancy C. Martin, ${ }^{1}$ Tim M. Townes, ${ }^{1}$ Richard D. Palmiter, ${ }^{3}$ \\ and Ralph L. Brinster ${ }^{2}$ \\ 'Department of Biochemistry, Schools of Medicine and Dentistry, University of Alabama at Birmingham, Birmingham, \\ Alabama 35294 USA; ${ }^{2}$ Laboratory of Reproductive Physiology, School of Veterinary Medicine, University of Pennsylvania, \\ Philadelphia, Pennsylvania 19104 USA; ${ }^{3}$ Department of Biochemistry, Howard Hughes Medical Institute, University of \\ Washington, Seattle, Washington 98195 USA
}

Erythroid-specific DNase I super-hypersensitive (HS) sites that are normally located far upstream of the human $\beta$-globin locus were inserted immediately upstream of a 4.1-kb fragment containing the human $\beta$-globin gene. These constructs (HS $\beta$ ) and a construct containing the $\beta$-globin gene alone $(\beta)$ were microinjected into fertilized mouse eggs, and expression was analyzed in erythroid fetal liver and brain of day-16 embryos that developed. Only 7 of 23 animals that contained the $\beta$ gene alone expressed human $\beta$-globin mRNA in erythroid tissue, and the average level of expression per gene copy was $0.3 \%$ of endogenous mouse $\beta$-globin mRNA. In contrast, 50 of 51 transgenic mice that contained various HS $\beta$ constructs expressed the transgene specifically in erythroid tissue. The average level of expression per gene copy for constructs containing all five upstream HS sites was $109 \%$ of endogenous mouse $\beta$-globin mRNA. Constructs that contained a single super-hypersensitive site (HS II $\beta$ ) expressed $40 \%$ as much human $\beta$-globin as mouse $\beta$-globin mRNA per gene copy. These results demonstrate that the HS VI site, normally located downstream of the human $\beta$-globin locus, is not required for high-level expression. Furthermore, the results demonstrate that high levels of human $\beta$-globin gene expression can be obtained in transgenic mice even when a relatively small fragment of DNA (1.9 kb) containing erythroid-specific super-hypersensitive site II (HS II) is inserted upstream of the human $\beta$-globin gene.

[Key Words: DNase I super-hypersensitive sites; locus activation sequences; tissue specificity]

Received December 14, 1988; revised version accepted January 23, 1989.

The human $\beta$-like globin genes are regulated precisely in three important ways: They are expressed only in erythroid tissue, only during defined stages of development, and at high levels. To determine the sequences responsible for these three levels of control, we and others have microinjected human globin gene constructs into fertilized mouse eggs and analyzed their expression in animals that developed (Costantini et al. 1985; Townes et al. 1985a,b; Kollias et al. 1986). These studies have demonstrated that sequences upstream, within, and downstream of the human $\beta$-globin gene are involved in adult, erythroid-specific expression (Behringer et al. 1987; Kollias et al. 1987; Trudel and Costantini 1987).

Although transgenic mice that express human $\beta$ globin mRNA at levels equivalent to mouse $\beta$-globin mRNA have been produced with relatively small human $\beta$-globin gene constructs, many of the animals express the transgene at low levels and others do not express the gene at all. Also, the highest expressors generally have the highest number of transgenes per cell. Recently, Grosveld et al. (1987) demonstrated that high levels of human $\beta$-globin gene expression can be obtained in animals with a single copy of the transgene if sequences at the extreme ends of the human $\beta$-globin locus are included in the injected constructs. Several years ago, Tuan et al. (1985) and Forrester et al. (1986) mapped sites that were super-hypersensitive to DNase I digestion in these regions. These DNase I super-hypersensitive (HS) sites are located $6-22 \mathrm{~kb}$ upstream of the $\epsilon$-globin gene and $19 \mathrm{~kb}$ downstream of the $\beta$-globin gene. The sites are present specifically in erythroid tissue at all stages of development. Figure 1 depicts the locations of these sites in the human $\beta$-globin locus.

The structure of mutant loci from patients with several hemoglobinopathies suggests that the upstream HS sites are required for efficient $\beta$-globin gene expression in humans (Bunn and Forget 1986; Stamatoyannopoulos et al. 1987). English and Dutch $\gamma \delta \beta$-thalassemias result from deletions that remove all of the upstream HS sites (Fig. 1). Although the $\beta$-globin gene is intact in these patients, no $\beta$-globin mRNA is produced from the mutant alleles. On the other hand, several other dele- 


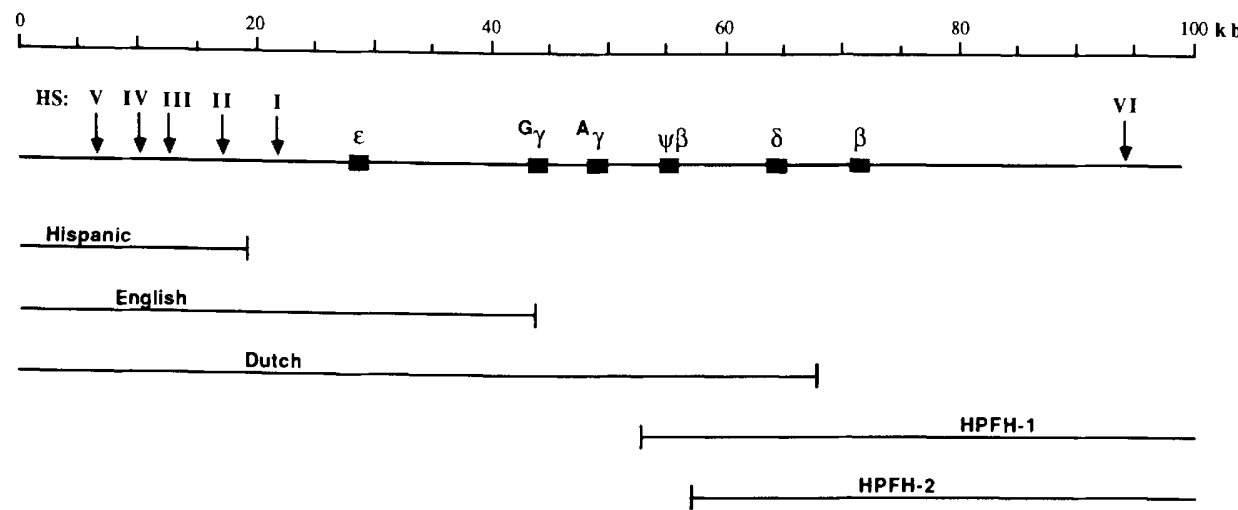

Figure 1. Human $\beta$-globin locus. A $100-\mathrm{kb}$ region of human chromosome 16 containing the $\beta$-like globin genes is illustrated. Erythroid-specific HS sites located 6-22 kb upstream of $\epsilon$ and $19 \mathrm{~kb}$ downstream of $\beta$ are marked by arrows (Tuan et al. 1985; Forrester et al. 1986). The lines beneath the locus represent deletions involved in Hispanic (C. Driscoll, pers. comm.), English, and Dutch $\gamma \delta \beta-$ thalassemias and two deletion forms of HPFH (Bunn and Forget 1986; Stamatoyannopoulos et al. 1987). The Hispanic patient described by C. Driscoll et al. (pers. comm.) has a $\beta^{s}$ allele on the affected chromosome but does not make any sickle hemoglobin.

tions suggest that the downstream site may not be essential. High levels of human $\gamma$-globin gene expression are observed in patients with two deletion forms of hereditary persistence of fetal hemoglobin (HPFH-1 and HPFH-2). Both of these mutant alleles lack the downstream super-hypersensitive site (HS VI; see Fig. 1). To determine whether the downstream site is required for high level expression of the human $\beta$-globin gene, we have made constructs containing all of the upstream sites but lacking the downstream site. These constructs were microinjected into fertilized mouse eggs, and the levels of human $\beta$-globin mRNA were analyzed in mice that developed. Constructs containing only HS I and HS II or HS II alone were also tested to determine the minimum number of $\mathrm{HS}$ sites required for high level expression of the human $\beta$-globin gene in transgenic mice.

\section{Results}

Production of HS $\beta$-globin transgenic mice

Figure 2 illustrates the seven constructs that were puri-

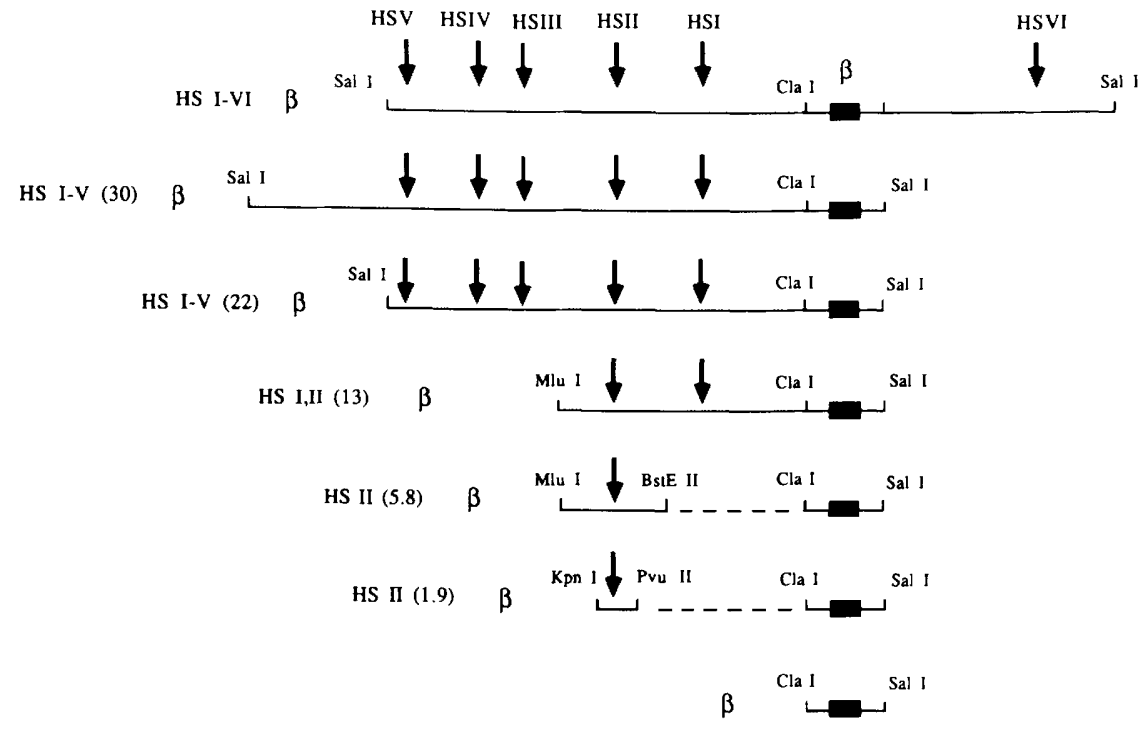

Figure 2. HS $\beta$ and $\beta$ constructs injected into fertilized mouse eggs. HS I-VI $\beta$, HS I-V (30) $\beta$, and HS I-V (22) $\beta$ were constructed from $\lambda$ clone fragments containing the HS sequences ( $\mathrm{Li}$ et al. 1985; D. Flenor and R. Kaufman, unpubl.). The numbers in parentheses represent the sizes of the upstream fragments in kilobase pairs. These fragments and a fragment containing the human $\beta$-globin gene were inserted into the cosmid vector pCV001, as described in Methods. HS I,II (13) $\beta$ and HS I (7.0) $\beta$ were derived from the HS I-V (22) $\beta$ cosmid clone. HS II (5.8) $\beta$ and HS II (1.9) $\beta$ were cloned as plasmids, as described in Methods. The $\beta$-globin gene in all of these constructs is on a $4.1-\mathrm{kb} \mathrm{HpaI-XbaI}$ fragment containing 815 bp of $5^{\prime}$-flanking sequence and $1700 \mathrm{bp}$ of $3^{\prime}$-flanking sequence. The HpaI site was changed to ClaI, and the XbaI site was changed to SalI in all constructs except HS I-VI $\beta$, where the XbaI site was changed to XhoI. In all cases, the fragments were cut out of cosmid or plasmid clones, purified from vector sequences on low gelling temperature agarose gels, and microinjected into fertilized mouse eggs as described by Brinster et al. (1985). 


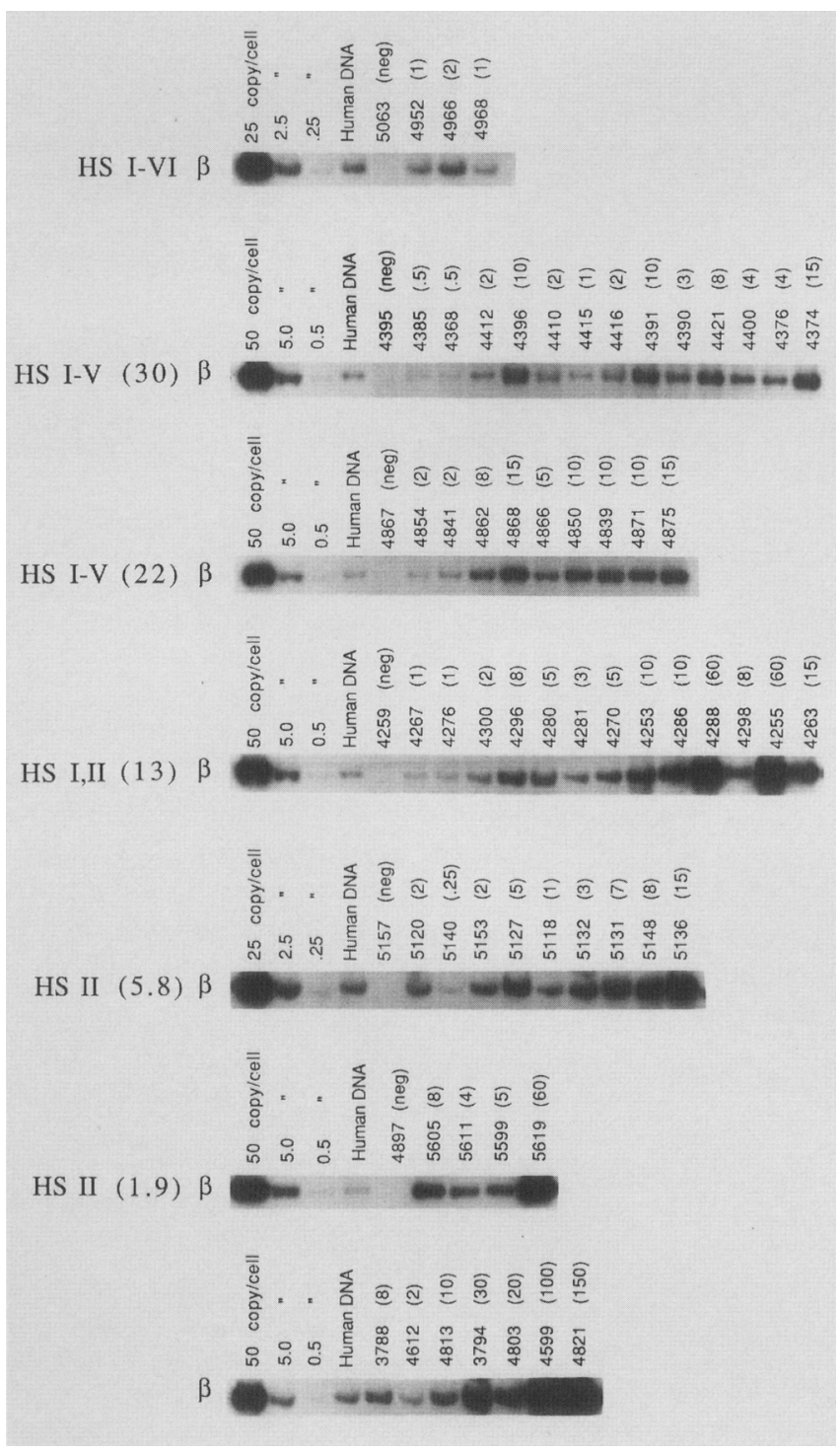

fied from vector sequences and injected into fertilized mouse eggs. These eggs were transferred into the uteri of psuedopregnant foster mothers, and the embryos were removed after 16 days of development. Total nucleic acids were prepared from the erythroid fetal livers and from brains, and transgenic mice were identified by DNA dot hybridization with $\beta$-globin and HS II-specific probes. Fetal liver DNA from positive animals was then analyzed by Southern blotting to determine transgene copy number and integrity. Figure 3 illustrates the Southern blots used to determine transgene copy number. Lanes 1-3 of each blot are herring sperm DNA spiked with the equivalent of $50,5.0$, and 0.5 or $25,2.5$, and 0.25 copies per cell of the respective construct; lane 4 is human DNA; and lane 5 is a nontransgenic mouse control. The controls and fetal liver DNA from each sample were digested with BamHI and PstI, and blots were hybridized with a human $\beta$-globin IVS 2 probe. A
Figure 3. Southern blot analysis of HS $\beta$ and $\beta$ transgenic mice. Ten micrograms of fetal liver DNA or control DNA was digested with BamHI and Pst and separated on $1.0 \%$ agarose gels. After blotting onto nitrocellulose, the samples were hybridized with a human $\beta$-globin-specific probe derived from the second intron. (Lanes 1-3) Herring sperm DNA spiked with the equivalent of $50,5.0$, and 0.5 or $25,2.5$, and 0.25 copies per cell of the respective construct; (lane 4) human DNA; (lane 5) a nontransgenic mouse control. The single $1.7-\mathrm{kb}$ band observed in all of the samples, except the negative controls, represents the fragment generated from digestion of the BamHI site in the second exon of the human $\beta$-globin gene and the PstI site located $559 \mathrm{bp}$ downstream of the poly(A) site. The intensity of this band was compared to the standards in lanes 1-4 to determine transgene copy number. The number of copies per cell of the transgene is listed in parenthesis after each sample number.

single 1.7-kb band was observed in all of the samples except the negative controls. The intensity of this band was compared to the standards in lanes 1-4 to determine transgene copy number. The number of copies per cell of the transgene is listed in parenthesis after each sample number. These values ranged from 0.25 to 150 copies per cell. Mice that contained less than one copy per cell are probably mosaics that integrated the transgene at the two- or four-cell stage. All of the samples were cut with several other enzymes and Southern blots were probed with various HS site and $\beta$-globin probes to determine transgene integrity (data not shown). All of the animals contained intact constructs except for samples 5140 and 5153 of HS II (5.8) $\beta$. Although the human $\beta$-globin gene was intact, the HS II site in both of these samples was rearranged.

\section{Expression of human $\beta$-globin mRNA in $H S \beta$ - transgenic mice}

Human and mouse $\beta$-globin mRNA levels were determined for each fetal liver and brain sample by solution hybridization with oligonucleotide probes as described previously (Townes et al. 1985b). In addition, fetal liver RNA was analyzed for correctly initiated human $\beta$ globin and mouse $\alpha$ - and $\beta$-globin mRNAs by primer extension. Mice switch directly from embryonic to adult hemoglobin synthesis when fetal liver becomes the major site of erythropoiesis at 13-17 days of development. Therefore, 16-day fetal liver is considered an adult erythroid tissue. Figure 4 illustrates the primer extension gel of fetal liver RNA from HS I-VI $\beta$ transgenic mice. The HS I-VI construct contains all five upstream and one downstream DNase I HS sites flanking the human $\beta$-globin gene (Fig. 2). Lane 1 is human reticulocyte RNA, and lane 2 is fetal liver RNA from a nontransgenic mouse control. The authentic human $\beta$ globin primer extension product is $98 \mathrm{bp}$, and the correct 


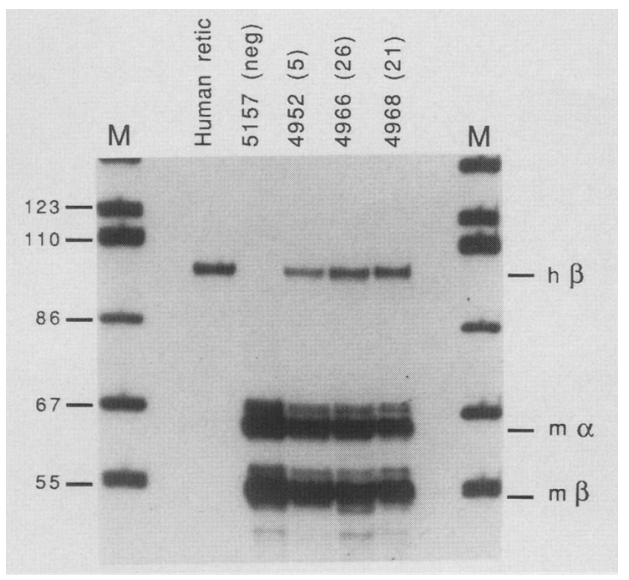

Figure 4. Primer extension analysis of fetal liver RNA from HS I-VI $\beta$ transgenic mice. Human $\alpha$-, mouse $\alpha$-, and mouse $\beta$-globin-specific oligonucleotides were end labeled with $\left[\alpha^{-32} \mathrm{P}\right] \mathrm{ATP}(3000 \mathrm{Ci} / \mathrm{mM})$ and hybridized together with $5 \mu \mathrm{g}$ of mouse fetal liver RNA or $0.5 \mu \mathrm{g}$ of human reticulocyte RNA and then extended with reverse transcriptase to map the $5^{\prime}$ ends of human $\beta$-, mouse $\alpha$-, and mouse $\beta$-globin mRNAs. The products were electrophoresed on an $8.0 \%$ urea-polyacrylamide gel, and the gel was autoradiographed for $8 \mathrm{hr}$ at $-70^{\circ} \mathrm{C}$ with an intensifying screen. The authentic human $\beta$-globin primer extension product is $98 \mathrm{bp}$, and the correct mouse $\alpha$ - and $\beta$-globin products are 65 and $53 \mathrm{bp}$, respectively. Markers are end-labeled HpaII fragments of the plasmid pSP64. Accurate quantitative values of human $\beta$-globin and mouse $\beta$-globin mRNAs were determined by solution hybridization with human $\beta$-globin and mouse $\beta$-globin-specific oligonucleotides as described by Townes et al. (1985b). Levels of human $\beta$-globin mRNA expressed as a percentage of endogenous mouse $\beta$ globin mRNA are listed in parenthesis after each sample number.

mouse $\alpha$ - and $\beta$-globin products are 65 and $53 \mathrm{bp}$, respectively. All three of the animals that contained the HS I-VI $\beta$ transgene expressed correctly initiated human $\beta$ globin mRNA; and the levels of expression; which are listed in parentheses after each sample number, ranged from 5.0 to $26 \%$ of endogenous mouse $\beta$-globin mRNA. As there are four copies of the mouse $\beta$-globin gene per diploid genome $\left(2 \beta^{\mathrm{s}}\right.$ and $2 \beta^{\mathrm{t}}$ alleles in the $\beta$ single haplotype mouse; Weaver et al. 1981), the levels of human and mouse $\beta$-globin mRNAs were divided by their respective gene copy numbers to make a direct comparison of expression. The corrected values for human $\beta$-globin mRNA ranged from 20 to $84 \%$ of endogenous mouse $\beta$ globin mRNA, and the average level of expression was $52 \%$ per gene copy (Table 1 ).

To determine whether the downstream HS VI site was required for high level human $\beta$-globin gene expression, a construct containing only the five upstream HS sites [HS I-V (30) $\beta$; Fig. 2] was analyzed in transgenic mice. This construct contains the five HS sites on a $30-\mathrm{kb}$ fragment linked upstream of the human $\beta$-globin gene. Thirteen animals that contained intact copies of the transgene were obtained, and all 13 expressed human $\beta$ globin mRNA in fetal liver. Figure 5 illustrates the primer extension gel of fetal liver RNA from the HS I-V
(30) $\beta$ construct. Levels of human $\beta$-globin mRNA ranged from 18 to $316 \%$ of endogenous mouse $\beta$-globin mRNA. When these values were corrected for transgene copy number, the average level of expression per gene copy was $108 \%$ of endogenous mouse $\beta$-globin mRNA (Table 1).

A construct that contained all five upstream HS sites on a smaller fragment $(22 \mathrm{~kb})$ was also assayed for activity. Nine animals containing intact copies of the HS I-V (22) $\beta$ transgene (Fig. 2) were obtained, and all nine expressed human $\beta$-globin mRNA in fetal liver. Fetal liver RNA from eight of these samples was analyzed by primer extension. The results are illustrated in Figure 6. All eight animals expressed correctly initiated human $\beta$ globin mRNA, and the levels of expression ranged from 52 to $380 \%$ of endogenous mouse $\beta$-globin mRNA. The lowest expressor (4854), which expressed human $\beta$ globin mRNA at $1.0 \%$ of the level of mouse $\beta$-globin mRNA, was not included on the gel. When the level of expression for all nine animals was corrected for transgene copy number, the average level of expression per gene copy was $109 \%$ of endogenous mouse $\beta$-globin mRNA (Table 1).

To determine whether all five upstream HS sites are required for high level erythroid expression, a construct containing only HS I and HS II on a $13-\mathrm{kb}$ MluI-ClaI fragment was inserted upstream of the human $\beta$-globin gene (Fig. 2) and tested for activity. Thirteen animals that contained intact copies of the HS I,II (13) $\beta$ trans-

Table 1. Summary of HS $\beta$ transgene expression

\begin{tabular}{lcccc}
\hline & \multicolumn{2}{c}{$\begin{array}{l}\text { Percent } \\
\text { endogenous } \\
\text { mouse } \beta \text {-globin }\end{array}$} & $\begin{array}{l}\text { Percent expression } \\
\text { per gene copy }\end{array}$ \\
\cline { 4 - 6 } Transgene & $\begin{array}{l}\text { Fraction } \\
\text { expressors }\end{array}$ & $\begin{array}{l}\text { mean } \\
\text { mRNA }^{\mathbf{a}}\end{array}$ & range \\
\hline HS I-VI $\beta$ & $3 / 3$ & $5-26$ & 52 & $20-84$ \\
HS I-V (30) $\beta$ & $13 / 13$ & $18-316$ & 108 & $16-200$ \\
HS I-V (22) $\beta$ & $9 / 9$ & $1-380$ & 109 & $2-208$ \\
HS I,II (13) $\beta$ & $13 / 13$ & $9-347$ & 49 & $9-92$ \\
HS II (5.8) $\beta$ & $6 / 7$ & $8-108$ & 40 & $6-84$ \\
HS II (1.9) $\beta$ & $4 / 4$ & $56-194$ & 40 & $13-63$ \\
$\beta$ & $7 / 23$ & $0.2-23$ & 0.3 & $0.1-0.6$ \\
\hline
\end{tabular}

Human and mouse $\beta$-globin mRNA levels were quantitated by solution hybridization with human $\beta$ - and mouse $\beta$-globin-specific oligonucleotides, as described (Townes et al. 1985). The values of percent expression per gene copy were calculated assuming four mouse $\beta$-globin genes per cell. Mice used in this study $(\mathrm{C} 57 \mathrm{BL} / 6 \times \mathrm{SJL}) \mathrm{F} 2$ have the $H b b^{S}$ or single haplotype. The $\beta$-globin locus in this haplotype contains two adult $\beta$ globin genes $\left(\beta^{S}\right.$ and $\left.\beta^{t}\right)$ per haploid genome (Weaver et al. 1981). These mice also have two $\alpha$-globin genes $(\alpha 1$ and $\alpha 2)$ per haploid genome (Whitney et al. 1981; Erhart et al. 1987). Copies per cell of HS $\beta$ transgenes were determined by densitometric scanning of the Southern blots illustrated in Fig. 3.

$$
\begin{aligned}
& \text { ( }\left(\frac{\mathrm{h} \beta \text { mRNA }}{\mathrm{m} \beta \mathrm{mRNA}} \times 100\right) . \\
& \mathrm{b}\left(\frac{\mathrm{h} \beta \mathrm{mRNA} / \mathrm{h} \beta \text { gene }}{\mathrm{m} \beta \mathrm{mRNA} / \mathrm{m} \beta \text { gene }} \times 100\right) .
\end{aligned}
$$




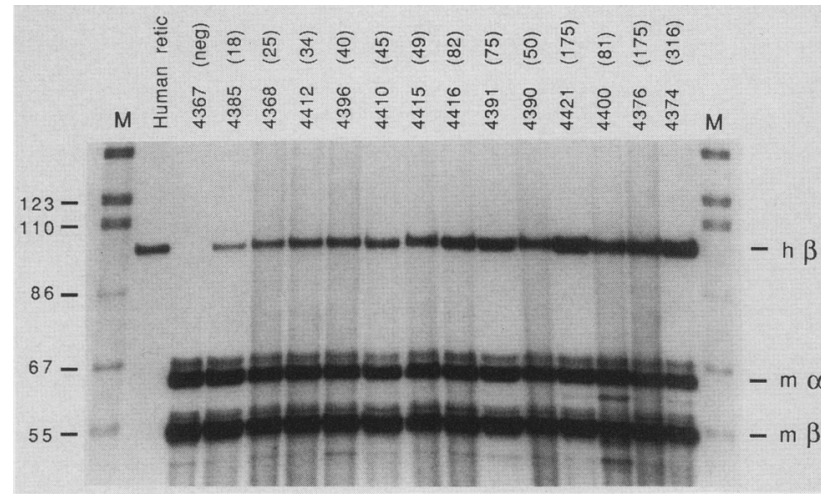

Figure 5. Primer extension analysis of fetal liver RNA from HS I-V $(30) \beta$ transgenic mice. As described in the legend to Fig. 4, $5 \mu \mathrm{g}$ of fetal liver RNA was analyzed.

gene were obtained, and all 13 animals expressed correctly initiated human $\beta$-globin mRNA in fetal liver (Fig. 7). Levels of expression ranged from 9.0 to $347 \%$ of endogenous mouse $\beta$-globin mRNA. When these values were corrected for transgene copy number, the average level of human $\beta$-globin expression was $49 \%$ of endogenous mouse $\beta$-globin expression (Table 1).

The 13.0-kb MluI-ClaI fragment containing HS I and HS II was then divided into a 5.8 -kb MluI-BstEII fragment containing HS II and a $7.2-\mathrm{kb}$ BstEII-ClaI fragment containing HS I. Each of these fragments was inserted upstream of the human $\beta$-globin gene (Fig. 2) and injected into fertilized eggs. Unfortunately, no HS I $\beta$ transgenic animals were obtained. However, nine animals containing the HS II $(5.8) \beta$ construct were identified by DNA dot hybridization, and seven of these nine animals contained intact copies of the transgene. Fetal liver RNA from all nine samples was analyzed by solution hybridization and primer extension, and eight of nine animals expressed correctly initiated human $\beta$ globin mRNA (Fig. 8). The single animal (5120) that did not express any human $\beta$-globin mRNA was the only

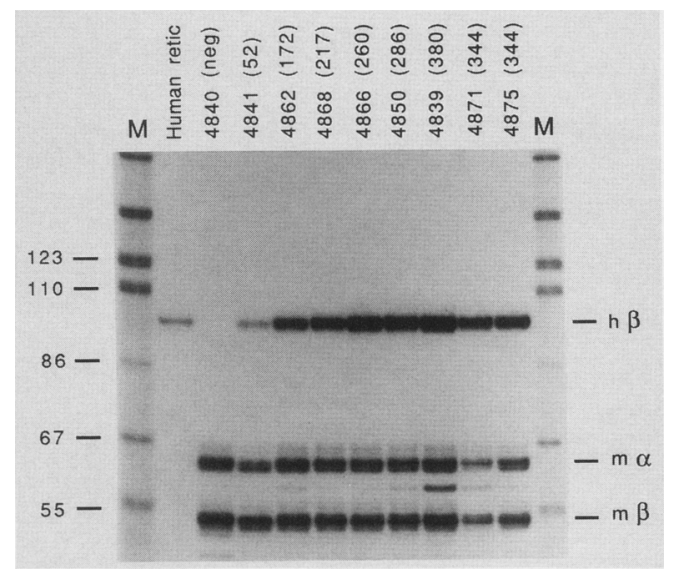

Figure 6. Primer extension analysis of fetal liver RNA from HS I-V (22) $\beta$ transgenic mice. As described in the legend to Fig. 4, $5 \mu \mathrm{g}$ of fetal liver RNA was analyzed.

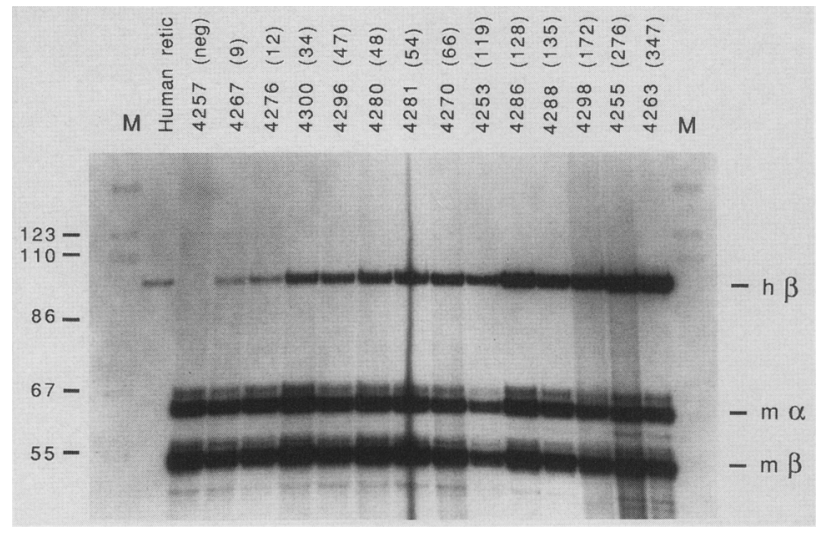

Figure 7. Primer extension analysis of fetal liver RNA from HS I,II (13) $\beta$ transgenic mice. As described in the legend to Fig. $4,5 \mu \mathrm{g}$ of fetal liver RNA was analyzed.

one of $51 \mathrm{HS} \beta$ transgenic animals that did not express the transgene. The levels of expression for samples 5140 and 5153 were low but, as described above, both of these samples contained rearranged copies of the transgene. Also, the fetal liver RNA of sample 5127 was somewhat degraded. The levels of human $\beta$-globin mRNA for samples $5127,5118,5132,5131,5148$, and 5136 ranged from 8.0 to $108 \%$ of endogenous mouse $\beta$-globin mRNA. When these levels were corrected for transgene copy number, the values ranged from 6.0 to $84 \%$, and the average level of human $\beta$-globin mRNA per gene copy was $40 \%$ of endogenous mouse $\beta$-globin mRNA (Table 1).

To begin to determine the minimal HS II sequence required for high level expression, a 1.9-kb KpnI-PvuII

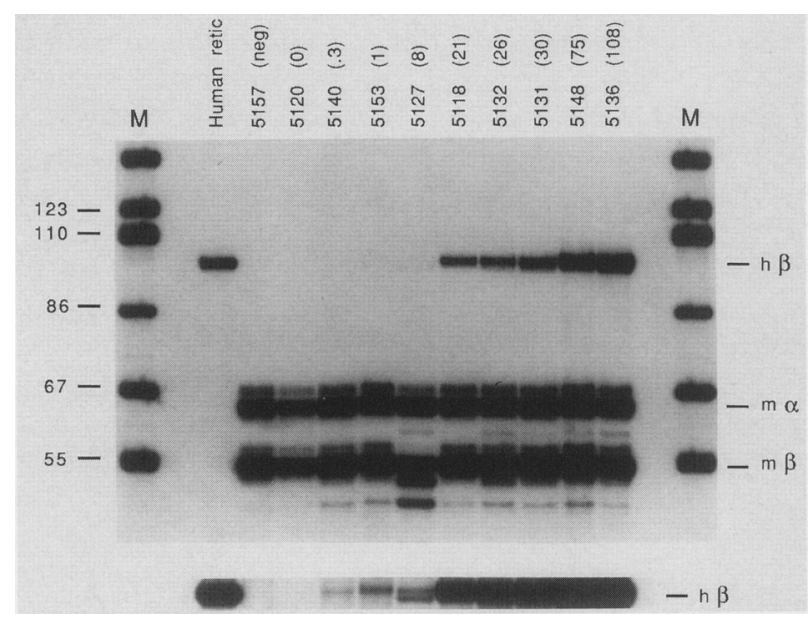

Figure 8. Primer extension analysis of fetal liver RNA from HS II (5.8) $\beta$ transgenic mice. As described in the legend to Fig. $1,5 \mu \mathrm{g}$ of fetal liver RNA was analyzed. (Bottom) A 3-day exposure of the human $\beta$-globin, 98-bp primer extension product is shown in the insert. Samples 5140 and 5153 contained rearranged copies of the transgene (data not shown), and the RNA from sample 5127 was degraded slightly. Sample 5120 was the only one of 51 transgenic mice that contained an intact copy of the transgene but did not express any human $\beta$-globin mRNA. 


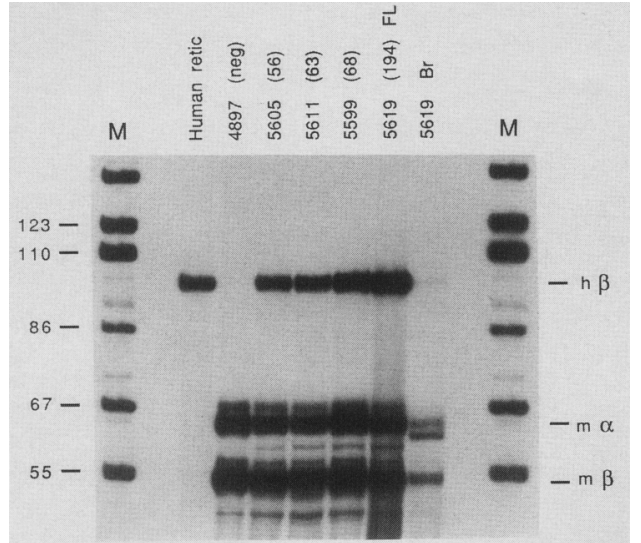

Figure 9. Primer extension analysis of fetal liver RNA from HS II (1.9) $\beta$ transgenic mice. As described in the legend to Fig. $4,5 \mu \mathrm{g}$ of fetal liver RNA was analyzed. Five micrograms of both fetal liver and brain RNA were analyzed for sample 5619 .

fragment containing HS II was inserted upstream of the human $\beta$-globin gene (Fig. 2) and tested for activity in transgenic mice. Four animals that contained intact copies of the transgene were obtained, and all four expressed correctly initiated human $\beta$-globin mRNA in fetal liver (Fig. 9). The levels of human $\beta$-globin mRNA ranged from 56 to $194 \%$ of endogenous mouse $\beta$-globin mRNA. When these values were corrected for transgene copy number, the average level of human $\beta$-globin mRNA was $40 \%$ of endogenous mouse $\beta$-globin mRNA (Table 1).

Finally, the human $\beta$-globin gene without HS sites was injected into fertilized eggs and assayed for expression in 16-day fetal liver. In this experiment, only 7 of 23 mice that contained intact copies of the transgene expressed human $\beta$-globin mRNA, and the levels of expression ranged from 0.2 to $23 \%$ of endogenous mouse $\beta$-globin mRNA. When these levels were corrected for transgene copy number, the average level of human $\beta$ globin mRNA was $0.3 \%$ of endogenous mouse $\beta$-globin mRNA (Table 1).

\section{Tissue specificity of HS $\beta$-globin transgene expression}

Fetal liver and brain RNA from the highest expressor of each set of transgenic animals were analyzed for human $\beta-$, mouse $\alpha$-, and mouse $\beta$-globin mRNA by primer extension to assess the tissue specificity of human $\beta$ globin gene expression. Data in Figure 10 and in the last two lanes of Figure 9 demonstrate that the human $\beta$ globin gene is expressed in fetal liver and not in brain. The small amount of human $\beta$-globin mRNA in the brain results from blood contamination because equivalent amounts of mouse $\alpha$ - and $\beta$-globin mRNA are also observed in this nonerythroid tissue. Solution hybridization analysis demonstrated that the ratio of human $\beta$ globin mRNA to mouse $\beta$-globin mRNA was virtually identical in fetal liver and brain in all $50 \mathrm{HS} \beta$ transgenic mice. These data strongly suggest that the HS sites act specifically in erythroid tissue to stimulate high levels of human $\beta$-globin gene expression in transgenic mice.

\section{Discussion}

\section{Summary of $H S \beta$-globin expression}

A summary of the results presented above are listed in Table 1 . In this study only 7 of 23 animals without HS sites expressed the transgene. In contrast, 50 of 51 animals that contained HS sites inserted upstream of the human $\beta$-globin gene expressed correctly initiated human $\beta$-globin mRNA in fetal liver and no expression was detected in fetal brain. These results, like those of Grosveld et al. (1987) with a construct containing HS I-VI $\beta$, suggest that the HS sites activate expression regardless of the site of transgene integration. However, expression is not totally position independent. The range of expression varied widely with all of the constructs tested, and levels of human $\beta$-globin mRNA were not absolutely correlated with transgene copy number. Nevertheless, the average levels of expression per gene copy were high for all of the HS $\beta$-globin constructs tested. The HS I-V $(30) \beta$ and HS I-V (22) $\beta$ constructs were expressed at an average level of 108 and $109 \%$, respectively, of endogenous mouse $\beta$-globin per gene copy, and all other HS $\beta$ constructs were expressed

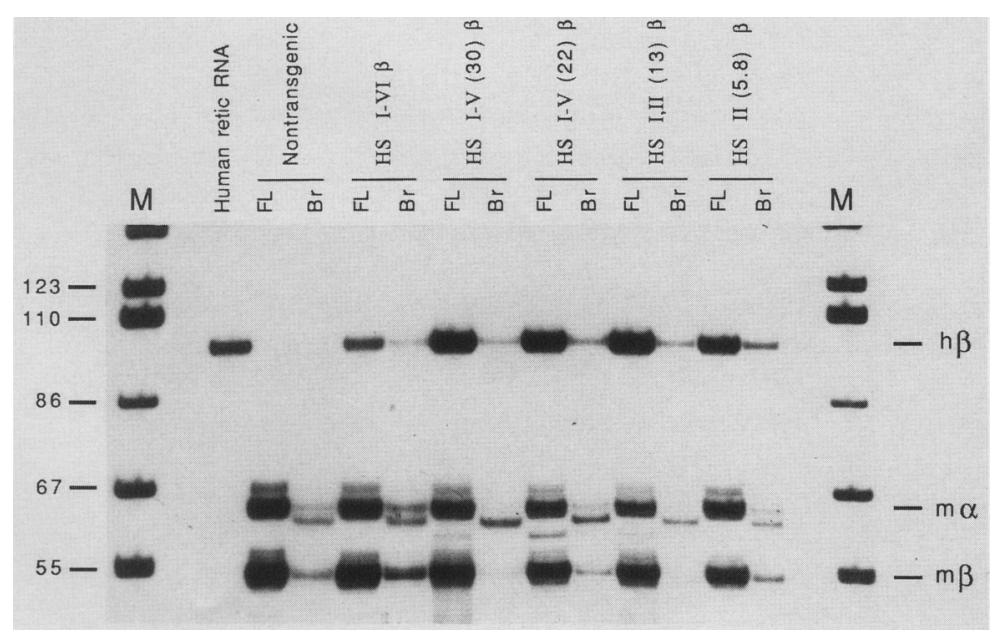

Figure 10. Primer extension analysis of fetal liver and brain RNA of HS $\beta$ transgenic mice. As described in the legend to Fig. 4, $5 \mu \mathrm{g}$ of fetal liver and brain RNA from the highest expressor of each set of HS $\beta$ transgenic mice were analyzed. The low level of human $\beta$-globin mRNA observed in the brain is the result of blood contamination because equivalent levels of mouse $\alpha$ - and $\beta$-globin mRNAs are also observed in this tissue. 
at $40-49 \%$ of endogenous mouse $\beta$-globin per gene copy. This high level of expression was obtained even when a 1.9-kb fragment containing only HS II was inserted upstream of the human $\beta$-globin gene. The average level of expression per gene copy for a human $\boldsymbol{\beta}$-globin construct that did not contain HS sites was only $0.3 \%$ of endogenous mouse $\beta$-globin. This average level of expression is 133-363 times lower than constructs containing HS sites. Finally, we suspect that the average level of expression for the HS I-VI $\beta$ construct was lower than $100 \%$ per gene copy because only three animals were obtained.

\section{Role of individual HS sites}

Southern blots of fetal liver DNA from all 51 of the HS $\beta$ transgenic mice generated in this study demonstrated head-to-tail tandem arrays of the transgene /data not shown). Therefore, every animal contains at least one copy of the human $\beta$-globin gene that is flanked on either side by HS sites. This is true even for animals that contain one or fewer copies per cell of the transgene. These animals must be mosaics (Wilke et al. 1986) with multiple tandemly linked transgenes in only a fraction of their cells. Although the data demonstrate that HS VI is not required for high level expression, a copy of HS II or one of the other upstream HS sites may substitute for HS VI when inserted downstream of the $\beta$-globin gene in the tandem array. To determine whether a downstream HS site is required for high level expression, animals containing a single copy of HS I-V $\beta$ or HS II $\beta$ will have to be produced.

We have not yet tested the activity of HS III, HS IV, or $\mathrm{HS} \mathrm{V}$, inserted individually upstream of the human $\beta$ globin gene. However, one or more of these sites may be active because transgenic animals that contain $\mathrm{HS} \mathrm{I}-\mathrm{V}$ consistently express higher levels of human $\beta$-globin mRNA than animals that contain HS I and HS II or HS II alone. Individual sites and various combinations of sites are now being tested to determine the minimal sequences required for maximal expression. As individual sites may be functionally redundant, it will also be interesting to test constructs containing multiple copies of HS II inserted upstream of the human $\beta$-globin gene to determine whether multimers of an individual site can substitute for HS I-V.

Because HS I $\beta$ transgenic animals were not obtained, we do not know whether HS I alone can stimulate $\beta$ globin gene expression. However, two pieces of data argue strongly that HS I is not sufficient to enhance expression. First, we have demonstrated recently that the human $\alpha$-globin gene is expressed at high levels in transgenic mice when placed downstream of HS I and HS II (Ryan et al. 1989). Of 12 HSI, HSII, $\alpha$-globin mice, 11 expressed correctly initiated human $\alpha$-globin mRNA specifically in erythroid tissue, and the average percent expression per gene copy was $57 \%$ of endogenous mouse $\beta$-globin mRNA. The single animal that did not express human $\alpha$-globin mRNA had intact copies of HS I $\alpha$ globin, but the HS II site had been deleted upon integration. This result suggests that HS I alone cannot en- hance expression. Second, a very interesting deletion in a Hispanic $\gamma \delta \beta$-thalassemic patient has recently been defined by C. Driscoll et al. (pers. comm.). A 30-kb deletion that ends $9.8 \mathrm{~kb}$ upstream of the $\epsilon$-globin gene removes HS V-II but leaves HS I intact (Fig. 1). The patient, who has a $\beta^{S}$ gene on this same chromosome, makes no sickle hemoglobin. The data from this patient and the transgenic animal described above strongly suggest that HS I cannot, by itself, stimulate expression of downstream globin genes.

\section{$H S$ site effect on other genes}

The effects of erythroid-specific HS sites on other tissue specifically expressed genes has not been tested. However, the experiments of Nandi et al. (1988) strongly suggest that the SV40 promoter can be dramatically influenced by HS sites. Murine erythroleukemia (MEL) cells containing human chromosome 11 were transfected with a construct containing a modified human $\beta$ globin gene and an SVneo gene. G418-resistant cells were identified that contained this construct inserted specifically into the human $\beta$-globin locus or at nonspecific chromosomal sites. When these cells were induced to differentiate with dimethylsulfoxide (DMSO), SVneo mRNA was induced to high levels in cells with site-specific integrants but not in cells with random integrants. These results strongly suggest that expression from heterologous promoters can be greatly enhanced by the HS sites. We have also demonstrated that SVneo expression is induced to high levels in MEL cells transfected with cosmids containing HS I-V $\beta$ linked to the SVneo gene (unpubl.).

\section{Human $\beta$-globin domain}

Several groups have suggested that HS sites mark the boundaries of the human $\beta$-globin domain and that these sites are responsible for opening the $\beta$-globin domain specifically in erythroid tissue (Tuan et al. 1985; Forrester et al. 1986, 1987; Grosveld et al. 1987). Forrester et al. (1987) have demonstrated recently that these HS sites are formed in human fibroblasts that have been fused with MEL cells. These hybrids synthesize high levels of human $\boldsymbol{\beta}$-globin mRNA. Presumably, trans-acting factors present in MEL cells interact with the hypersensitive site sequences both upstream and downstream of the human $\beta$-globin locus and organize the previously closed chromatin domain into an open domain. Therefore, Forrester et al. (1987) have suggested that the sequences be called 'locus activating regions,' or LARs. Similarly, in the developing human embryo, transacting factors present in early erythroid cells may interact with hypersensitive site sequences and activate the $\beta$-globin locus for expression.

\section{Model for developmental regulation}

Choi and Engel (1988) have demonstrated recently that sequences at the immediate $5^{\prime}$ end of the chicken $\beta$ - 
globin gene are involved in temporal specificity in transient expression assays. These sequences apparently bind factors that influence the ability of this promoter to compete with the $\epsilon$-globin gene promoter for interactions with a single erythroid enhancer (Choi and Engel 1988; Nickol and Felsenfeld 1988) located in the chicken $\beta$-globin locus. Although similar mechanisms may be involved in developmental stage-specific expression of human globin genes, the situation is probably more complex. The major determinants of erythroid tissue specificity in humans appear to be the HS sequences. In fact, these sequences carry out two important functions: They organize the entire $\beta$-globin locus for expression specifically in erythroid tissue, and they act as an enhancer to direct high level expression. These two separate but related functions are evident in the experiments described above. First, the HS sites increase the fraction of transgenic animals that express the human $\beta$-globin gene. Of $51 \mathrm{HS} \beta$-globin mice, 50 expressed the transgene specifically in erythroid tissue compared with 7 of 23 animals containing the $\beta$-globin gene alone. Apparently, the HS sequences ensure that the transgene will be in an open chromatin domain regardless of the site of integration. Second, HS sites stimulated the average level of $\beta$-globin gene expression 133- to 363 -fold compared to the average level of the $\beta$-globin gene alone. Therefore, these sequences constitute a powerful enhancer that may work in concert with enhancers in and surrounding individual genes.

Although human $\beta$-globin genes in transgenic mice are expressed specifically in adult erythroid tissue without HS sites, high levels of correctly regulated expression may require interactions between HS sequences, promoters, and proximal enhancers. A model for globin gene regulation can be envisioned that incorporates the two important functions of HS sites and the concept of competition between various regulatory sequences. HS sequences could be activated in early erythroid cell precursors and organize the entire $\beta$-globin locus into an open chromatin domain that is stable throughout development. Within the open domain, promoters and enhancers in and surrounding the $\epsilon^{-}, \gamma^{-}$, and $\beta$-globin genes could then compete for interactions with the HS master enhancer to determine which of these genes will be expressed. Promoter and proximal enhancer binding factors synthesized in yolk sac, fetal liver, and bone marrow could influence these competitive interactions either positively or negatively and subsequently determine developmental specificity. Transgenic mouse experiments with constructs containing human $\epsilon_{-}, \gamma-$, and $\beta$-globin genes inserted separately or in various combinations downstream of the HS sites should help define important interactions between regulatory sequences and should, in general, provide meaningful insights into the complex mechanisms that regulate multigene families during development.

\section{Methods}

Construction of HS $\beta$-globin clones

Lambda clones containing HS sites I-IV $\left[5^{\prime} \in \mathrm{EI}\right.$ and $5^{\prime} \mathrm{\epsilon II}$; Li et al. 1985) were kindly provided by Oliver Smithies, and a $\lambda$ clone containing HS VI $(\lambda 4)$ was kindly provided by Don Fleenor and Russell Kaufman. A 1.9-kb HindIII fragment containing HS III was prepared from $5^{\prime} \in \mathrm{EII}$ and subcloned into pUC19. A $1.3-\mathrm{kb}$ BamHI-HindIII fragment from this plasmid was then used to screen a human placenta genomic library in EMBL 4 (Stratagene) and several clones that overlapped with $5^{\prime} \in$ III were isolated. One clone that contained a 17.5-kb insert extended $\sim 11.0$ $\mathrm{kb}$ upstream of the EcoRI site at the $5^{\prime}$ end of the $5^{\prime} \in$ III clone. This new clone, which was designated $5^{\prime} \in I V$, contained HS V. Cosmid clone HS I-V (30) $\beta$ was constructed as follows. A $17-\mathrm{kb}$ SalI-MluI fragment was prepared from $5^{\prime} \epsilon \mathrm{IV}$; the SalI site was from the EMBL 4 SalI-BamHI cloning site, and the MluI site was a natural site in the insert. This $17-\mathrm{kb}$ fragment contained HS V, HS IV, and HS III. A 13-kb MluI-ClaI fragment containing HS II and HS I was prepared from 5 ' $\epsilon$ II. These two fragments were inserted into the cosmid vector pCV001 (Lau and Kan 1983 in a four-way ligation. The left arm was a 9.0-kb MluI-Sall fragment obtained from pCV001; the MluI site was destroyed by $\mathrm{Sl}$ digestion. This fragment contained a cos site, an ampicillin-resistance gene, a ColEI origin, and the SVneo gene. The right arm was a 6.6-kb ClaI-HindIII fragment that contained the human $\beta$-globin gene on a $4.1-\mathrm{kb} H$ paI-XbaI fragment and a cos site from pCV001 on a $2.5-\mathrm{kb}$ SalI-HindIII fragment. The $H p a I$ and $X b a I$ sites on either side of the $\beta$-globin gene were changed to ClaI and Sall, respectively, in the right arm plasmid.

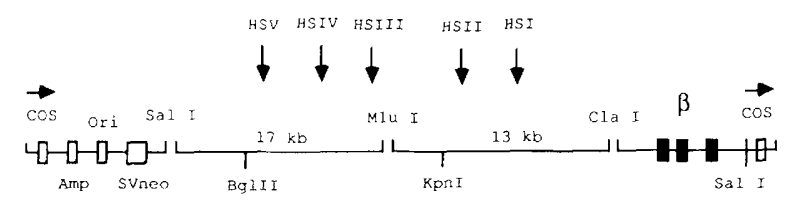

These four fragments were ligated in a $2: 1: 1$ vector arms to inserts and packaged (Gigapack Gold; Stratagene). Escherichia coli ED8767 was then infected with the packaged cosmids and plated on ampicillin plates. Large-scale cultures of ampicillinresistant colonies were grown and cosmids were prepared by standard procedures (Maniatis et al. 1982).

The HS I-V (22) $\beta$ cosmid was constructed as follows. A $12-\mathrm{kb}$ BgllI fragment containing HS V, HS IV, HS III, and HS II was subcloned from HS I-V $\{30\} \beta$ into a modified pUC plasmid, and a $10.7-\mathrm{kb}$ Sall-KpnI fragment containing HS V, HS IV, and HS III was prepared from this plasmid. The Sall site of this fragment was from the pUC polylinker, and the KpnI site was a natural site in the insert. A 10.9-kb KpnI-ClaI fragment containing HS II and HS I was isolated from $5^{\prime} \epsilon \mathrm{II}$ and subcloned into a modified pUC plasmid. The $10.7-\mathrm{kb}$ Sall-Kpnl fragment containing HS V, HS IV, and HS III was ligated to the 10.9-kb KpnI-ClaI fragment containing HS II and HS I and the two cosmid vector arms described above. The ligation mixture was packaged, ED8767 cultures were infected, and cosmids were prepared from ampicillin-resistant colonies.

HS I-VI $\beta$ was prepared as follows. A $12.0-\mathrm{kb} H p a I-B a m H I$ fragment containing HS VI was subcloned from $\lambda 4$ into a modified pUC19 plasmid and then isolated from this plasmid as a $12.0-\mathrm{kb}$ XhoI-Sall fragment. This fragment was cloned into the Sall site downstream of the human $\beta$-globin gene in the rightarm plasmid described above. The right-arm plasmid was then linearized with $\mathrm{ClaI}$ and dephosphorylated with calf intestinal phosphatase (Boehringer-Mannheim). This 21-kb right-arm fragment and the 9.0-kb MluI-SalI left-arm fragment described above were ligated with the 10.7-kb SalI-KpnI fragment containing HS V, HS IV, and HS III and the 10.9-kb KpnI-ClaI frag- 
ment containing HS II and HS I in a $2: 1: 1$ molar ratio of vector arms to inserts. The ligation mixture was packaged, ED8767 cultures were infected, and cosmids were prepared from ampicillin-resistant colonies.

HS I,II (13) $\beta$ was derived from HS I-V (22) $\beta$ after digestion with MluI and SalI. HS II $(5.8) \beta$ and HS II (1.9) $\beta$ were constructed by subcloning the $5.8-\mathrm{kb}$ MluI-BstEII fragment or the 1.9-kb KpnI-PvuII fragment into modified pUC plasmids containing the human $\beta$-globin gene.

\section{Sample preparation and microinjection}

All of the constructs were removed from vector sequences by digestion with the appropriate enzymes and isolated on lowgelling temperature agarose (FMC) gels. Gel slices were melted, extracted twice with phenol [buffered with $0.1 \mathrm{M}$ Tris $-\mathrm{HCl} / \mathrm{pH}$ 8.0 ), $1.0 \mathrm{mM}$ EDTA], once with phenol/chloroform, and once with chloroform and precipitated with ethanol. After resuspension in TE [10 mM Tris- $\mathrm{HCl}$ (pH 8.0), $1.0 \mathrm{mM}$ EDTA], the fragments were again extracted with phenol, phenol/chloroform, and chloroform and precipitated with ethanol. The purified fragments were washed with $70 \%$ ethanol, resuspended in sterile $\mathrm{TE}$, and microinjected into the male pronuclei of F2 hybrid eggs from C57BL/ $6 \times$ SJL parents as described by Brinster et al. (1985).

\section{DNA analysis}

Total nucleic acids were prepared from 16-day fetal liver and brain, as described previously (Brinster et al. 1985). Samples that contained the injected constructs were determined by DNA dot hybridization of brain nucleic acids with human $\beta$ globin and HS II-specific probes that were labeled by extension of random primers (Feinberg and Vogelstein 1983). The human $\beta$-globin probe was a 790-bp Hinfl fragment from IVS 2 , and the HS II probe was a 1.9-kb HindIII fragment spanning the HS II site. Hybridizations were performed at $68^{\circ} \mathrm{C}$ for $16 \mathrm{hr}$ in $5 \times$ SSC, $5 \times$ Denhardt's solution, $100 \mu \mathrm{g} / \mathrm{ml}$ herring sperm DNA, and $0.1 \%$ SDS. Filters were washed three times for $20 \mathrm{~min}$ each at $68^{\circ} \mathrm{C}$ in $2 \times \mathrm{SSC}$, and $0.1 \%$ SDS and for $20 \mathrm{~min}$ at $68^{\circ} \mathrm{C}$ in $0.2 \times$ SSC and $0.1 \%$ SDS if necessary to reduce background.

For Southern blots, $10 \mu \mathrm{g}$ of fetal liver DNA from animals that were positive with HS II and/or $\beta$-globin probes were digested with BamHI and PstI, electrophoresed on $1.0 \%$ agarose gels, blotted onto nitrocellulose, and hybridized with the $\beta$ and HS II probes described above. The hybridization conditions for Southern blots were the same as described for DNA dots.

\section{RNA analysis}

RNA was prepared from total nucleic acids by digesting the sample with DNase I (Worthington, RNase-free) at $10 \mu \mathrm{g} / \mathrm{ml}$ for $20 \mathrm{~min}$ at $37^{\circ} \mathrm{C}$ in $10 \mathrm{mM}$ Tris- $\mathrm{HCl}(\mathrm{pH} 7.5), 10 \mathrm{mM} \mathrm{MgCl}$, and $50 \mathrm{~mm} \mathrm{NaCl}$. The reaction was stopped with EDTA, and the sample was digested with proteinase $\mathrm{K}(100 \mu \mathrm{g} / \mathrm{ml})$ for $15 \mathrm{~min}$ at $37^{\circ} \mathrm{C}$. After digestion, RNA was purified by phenol/chloroform and chloroform extraction, precipitated with ethanol, and resuspended in TE.

Quantitation of human and mouse $\beta$-globin mRNA was determined by solution hybridization with oligonucleotide probes as described (Townes et al. 1985b). Primer extensions were performed as described by Townes et al. (1985a,b), except that only $5 \mu \mathrm{g}$ of fetal liver or brain RNAs were analyzed and three oligonucleotides were used in each reaction. The human $\beta$ primer 5'-AGACGGCAATGACGGGACACC- $3^{\prime}$ corresponds to sequences from +78 to +98 of the human $\beta$-globin gene. The mouse $\alpha$ primer 5'-CAGGCAGCCTTGATGTTGCTT-3' corresponds to sequences from +45 to +65 of the mouse $\alpha 1$ - and $\alpha 2$-globin genes, which are identical in this region. The mouse $\beta$ primer 5'-TGATGTCTGTTTCTGGGGTTGTG-3' corresponds to sequences +31 to +53 of the mouse $\beta^{\mathrm{s}}$-globin gene. Although there are 2-bp differences in the $\beta^{\mathrm{s}}$ and $\beta^{\mathrm{t}}$ genes in the region covered by this oligonuceotide, comparison of solution hybridization results /obtained with a different oligonucleotide that is perfectly complimentary to $\beta^{\mathbf{S}}$ and $\beta^{\mathbf{t}}$; see Townes et al. $1985 \mathrm{~b}$ ) with primer extension data suggests that the primer anneals with equal efficiency to $\beta^{s}$ - and $\beta^{t}$-globin mRNA under the hybridization conditions used.

\section{Acknowledgments}

We thank Oliver Smithies for $\lambda$ clones $5^{\prime} \in I I$ and $5^{\prime} \in I I I$ and Don Flenor and Russell Kaufman for $\lambda 4$. We especially thank Cathy Driscoll for communicating results on the Hispanic thalassemia prior to publication. We also thank Josef Prchal for providing human reticulocyte RNA and Jeff Engler for synthesizing the human $\beta$ - and mouse $\beta$-globin oligonucleotides. This work was supported, in part, by grants HL-35559, HD-09172, and HD-17321 from the National Institutes of Health. T.M.R. is a predoctoral trainee supported by National Institutes of Health grant T32 CA-09467.

\section{References}

Behringer, R.R., R.E. Hammer, R.L. Brinster, R.D. Palmiter, and T.M. Townes. 1987. Two $3^{\prime}$ sequences direct adult erythroid-specific expression of human $\beta$-globin genes in transgenic mice. Proc. Natl. Acad. Sci. 84: 7056-7060.

Brinster, R.L., H.Y. Chen, M.E. Trumbauer, M.K. Yagle, and R.D. Palmiter. 1985. Factors affecting the efficiency of introducing foreign DNA into mice by microinjecting eggs. Proc. Natl. Acad. Sci. 82: 4438-4442.

Bunn, H.F. and B.G. Forget. 1986. Hemoglobin: Molecular, genetic, and clinical aspects. W.B. Saunders, Philadelphia.

Choi, Ok-Ryun and J.D. Engel. 1988. Developmental regulation of $\beta$-globin gene expression. Cell 55: 17-26.

Costantini, F., G. Radice, J. Magram, G. Stamatoyannopoulos, and T. Papayannopoulou. 1985. Developmental regulation of human globin genes in transgenic mice. Cold Spring Harbor Symp. Quant. Biol. 50: 361-370.

Erhart, M.A., K. Piller, and S. Weaver. 1987. Polymorphism and gene conversion in mouse $\alpha$-globin haplotypes. Genetics 115: $511-519$.

Feinberg, A.P. and B. Vogelstein. 1983. A technique for radiolabeling DNA restriction endonuclease fragments to high specific activity. Anal. Biochem. 132: 6-13.

Forrester, W., C. Thompson, J.T. Elder and M. Groudine. 1986. A developmentally stable chromatin structure in the human $\beta$-globin gene cluster. Proc. Natl. Acad. Sci. 83: 1359-1363.

Forrester, W., S. Takagawa, T. Papayannopoulou, G. Stamatoyannopoulos, and M. Groudine. 1987. Evidence for a locus activation region: The formation of developmentally stable hypersensitive sites in globin-expressing hybrids. Nucleic Acids Res. 15: 10159-10177.

Grosveld, F., G.B. van Assendelft, D.R. Greaves, and G. Kollias. 1987. Position-independent, high-level expression of the human $\beta$-globin gene in transgenic mice. Cell 51: 75-85.

Kollias, G, J. Hurst, E. deBoer, and F. Grosveld. 1987. The human $\beta$-globin gene contains a downstream developmental specific enhancer. Nucleic Acids Res. 15: 5739-5747.

Kollias, G., N. Wrighton, J. Hurst, and F. Grosveld. 1986. Regu- 
lated expression of human A $\gamma-, \beta-$, and hybrid $\gamma / \beta$-globin genes in transgenic mice: Manipulation of the developmental expression patterns. Cell 46: 89-94.

Lau, Y.F. and Y.W. Kan. 1983. Versatile cosmid vectors for the isolation, expression, and rescue of gene sequences: Studies with the human $\alpha$-globin gene cluster. Proc. Natl. Acad. Sci. 80: $5225-5229$.

Li, Q., P.A. Powers, and O. Smithies. 1985. Nucleotide sequence of 16-kilobase pairs of DNA $5^{\prime}$ to the human -globin gene. J. Biol. Chem. 260: 14901-14910.

Maniatis, T., E. Fritsch, and J. Sambrook. 1982. Molecular cloning: A laboratory manual. Cold Spring Harbor Laboratory, Cold Spring Harbor, New York.

Nandi, A.K., R.S. Roginski, R.G. Gregg, O. Smithies, and A.I. Skoultchi. 1988. Regulated expression of genes inserted at the human chromosomal $\beta$-globin locus by homologous recombination. Proc. Natl. Acad. Sci. 85: 3845-3849.

Nickol, J.M. and G. Felsenfeld. 1988. Bidirectional control of the chicken $\beta$ - and -globin genes by a shared enhancer. Proc. Natl. Acad. Sci. 85: 2548-2552.

Ryan, T.M., R.R. Behringer, T.M. Townes, R.D. Palmiter, and R.L. Brinster. 1989. High-level erythroid expression of human $\alpha$-globin genes in transgenic mice. Proc. Natl. Acad. Sci. 86: $37-41$.

Stamatoyannopoulos, G., A.W. Nienhuis, P. Leder, and P.W. Majerus. 1987. Molecular basis of blood diseases. W.B. Saunders, Philadelphia.

Townes, T.M., H.Y. Chen, J.B. Lingrel, R.L. Palmiter, and R.L. Brinster. 1985a. Expression of human $\beta$-globin genes in transgenic mice: Effects of a flanking metallothioneinhuman growth hormone fusion gene. Mol. Cell. Biol. 5: $1977-1983$.

Townes, T.M., J.B. Lingrel, H.Y. Chen, R.L. Brinster, and R.D. Palmiter. 1985b. Erythroid-specific expression of human $\beta$ globin genes in transgenic mice. EMBO /. 4: 1715-1723.

Trudel, M. and F. Costantini. 1987. A 3' enhancer contributes to the stage-specific expression of the human $\beta$-globin gene. Genes Dev. 1: 954-961.

Tuan, D., W. Soloman, Q. Li, and I. London. 1985. The $\beta$-likeglobin gene domain in human erythroid cells. Proc. Natl. Acad. Sci. 82: 6384-6388.

Weaver, S., M.B. Comer, C.L. Jahn, C.A. Hutchison, and M.H. Edgell. 1981. The adult $\beta$-globin genes of the 'single' type mouse C57BL. Cell 24: 403-411.

Whitney, J.B. III, R.R. Cobb, R.A. Popp, and T.W. O'Rourke. 1981. Deletions in the $\alpha$-globin gene complex in $\alpha$-thalassemic mice. Proc. Natl. Acad. Sci. 78: 7644-7647.

Wilke, T.M., R.L. Brinster, and R.D. Palmiter. 1986. Germ line and somatic mosaicism in transgenic mice. Dev. Biol. 118: 9-18. 


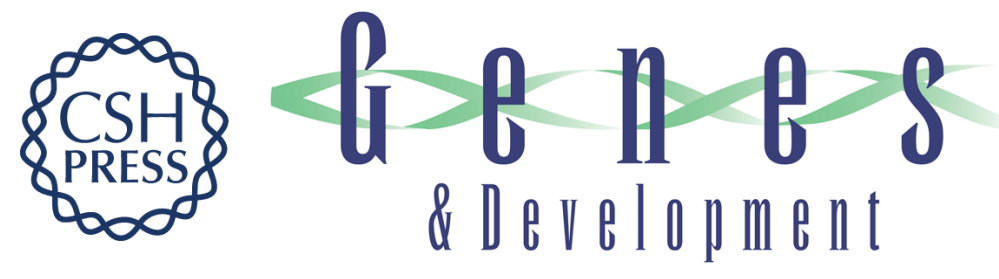

\section{A single erythroid-specific DNase I super-hypersensitive site activates high levels of human beta-globin gene expression in transgenic mice.}

T M Ryan, R R Behringer, N C Martin, et al.

Genes Dev. 1989, 3:

Access the most recent version at doi:10.1101/gad.3.3.314

References This article cites 23 articles, 14 of which can be accessed free at: http://genesdev.cshlp.org/content/3/3/314.full.html\#ref-list-1

License

Email Alerting Service

Receive free email alerts when new articles cite this article - sign up in the box at the top right corner of the article or click here.

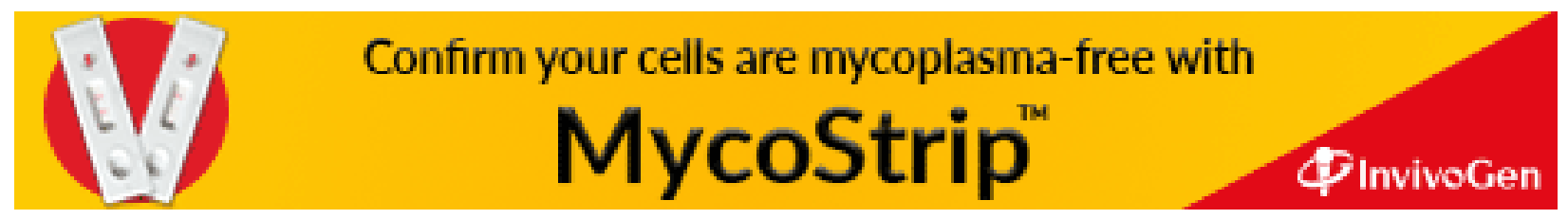

